\title{
Phytoplasma Identity and Disease Etiology
}

\author{
R. E. Davis and W. A. Sinclair
}

First author: Molecular Plant Pathology Laboratory, Agricultural Research Service-USDA, Beltsville, MD 20705; second author: Department of Plant Pathology, Cornell University, Ithaca, NY 14853-4203.

Accepted for publication 18 September 1998.

\begin{abstract}
Davis, R. E., and Sinclair, W. A. 1998. Phytoplasma identity and disease etiology. Phytopathology 88:1372-1376.

Many plant diseases believed to be caused by phytoplasmas were described before phytoplasma groups were delineated through molecular analyses. It is now possible to assess the relationships between phytoplasma identity or classification and specific plant diseases. Data were consistent with the hypothesis of a common ancestral origin of pathogenicity genes in many phytoplasmas and a limited repertoire of plant responses to certain pathogen signals. Observations also were consistent with the hypotheses that the botanical host ranges of some phytoplasmas
\end{abstract}

ABSTRACT

In plant pathology, as in human and animal medicine, not only pathogens but also the diseases they cause historically have been named largely on the basis of symptoms exhibited by infected hosts. Plant diseases attributed to phytoplasmas are no exception to this practice. For example, many phytoplasmal diseases have been classified in general terms, either as decline or virescence diseases. Disease names, such as aster yellows, strawberry multiplier, pear decline, palm lethal yellows, and others, indicate the importance of perceived symptoms in the assignment of common names to diseases. Indeed, common names of pathogens are derived from the names of plant diseases with which they are first associated.

Studies of phytoplasmal disease etiology usually have proceeded under the presumption that specific phytoplasmas cause specific diseases. This concept was established even before putative phytoplasma taxa were differentiated and proved correct for some diseases (e.g., apple proliferation, ash yellows, and elm yellows [31, 41,43]). However, it has become clear that different phytoplasmas can cause apparently identical symptoms in certain plants, including phytoplasmas associated with grapevine yellows, bigbud of tomato, and disorders of periwinkle (Catharanthus roseus) $(2,6,8$, $11,22,38,42)$. On the other hand, some closely related phytoplasmas can cause distinctly different symptoms in host plants. For example, the syndromes induced by aggressive and nonaggressive strains of ash yellows phytoplasmas in experimentally infected green ash (Fraxinus pennsylvanica) differ dramatically (W. A. Sinclair, unpublished data). Closely related strains in a single subcluster (subgroup) of the aster yellows genomic cluster (group) can induce either phyllody or small flowers of normal color in infected periwinkle plants. Such observations and the occurrence of

Corresponding author: R. E. Davis; E-mail address: rdavis@asrr.arsusda.gov

Publication no. P-1998-1027-010

This article is in the public domain and not copyrightable. It may be freely reprinted with customary crediting of the source. The American Phytopathological Society, 1998. reflect specificities in transmission by vectors and vector feeding preferences; phytoplasma-insect vector relationships are keys to understanding evolutionary divergence of phytoplasma lineages; small differences in a highly conserved phytoplasma gene may be regarded as potential indicators of separate gene pools; the reliability of a diagnosis based on symptoms must be learned empirically (i.e., through case study for each syndrome); and some discrete diseases can be ascribed to phytoplasma taxa at the 16S rRNA group level, whereas others are clearly associated with phytoplasma taxa below this level.

Additional keywords: evolution, mycoplasmalike organism, taxonomy. natural infections by mixed phytoplasma populations $(2,3,15,24)$ can hamper disease diagnosis and complicate attribution of a disease to a single phytoplasma taxon.

In this paper, we present a brief assessment of the relationship between classification of phytoplasmas and differentiation of their associated plant diseases. These considerations are important for understanding phytoplasma biology and for successful disease management and regulation of interregional and international shipment of plants that potentially harbor phytoplasmas.

\section{PHENOTYPIC CHARACTERS AND PHYTOPLASMA CLASSIFICATION}

Because phytoplasmas cannot yet be isolated in pure culture in vitro, phenotypic characters useful for identification and classification have been difficult to determine. Molecular characterization of conserved genes has presented a partial solution to the problem, enabling the construction of a classification scheme that is independent of phenotypic characters. Several studies of $16 \mathrm{~S}$ rRNA gene sequences have confirmed the appropriate placement of phytoplasmas within the class Mollicutes and have led to recognition of phytoplasmas as a distinct monophyletic clade within the class (16). Phytoplasmas have been classified into more than a dozen groups (Table 1); each group apparently corresponds to at least one species (also listed in Table 1 of Lee et al. [25]). This concept is supported by studies on genes that encode rRNA, ribosomal protein, and the elongation factor $\mathrm{Tu}(8,15-17,19,21,26,29,36,39$, 41,44).

Many plant diseases believed to be caused by phytoplasmas were described before phytoplasma groups were delineated through DNA analyses. It is now possible to assess the relationship between phytoplasma identity or classification and specific plant diseases. The presence, absence, or magnitude of a phenotypic character can be assessed for each phytoplasma strain, and phytoplasma taxa can be compared for characters, such as plant and insect host ranges and propensity to induce particular symptoms, 
such as hyperplasia, phyllody, or witches'-brooms. Schneider and Seemüller (40) assessed the molecular classification of phytoplasmas associated with four symptom types on periwinkle. They found that apart from the virescence-inducing organisms of the aster yellows group (sensu lato), there was no consistent relationship between symptom type and phytoplasma group identity. Previously, Lee et al. (22) determined that different disease symptoms could be induced in a host plant by closely related strains classified in the same subcluster (subgroup) in the aster yellows phytoplasma genomic cluster.

Because descriptions of organisms cultured in vitro are required for naming of species in the class Mollicutes and phytoplasmas cannot yet be isolated in culture, phytoplasma lineages are being referred to as "Candidatus Phytoplasma species." Two provisional species have been named: Candidatus Phytoplasma aurantifolia (47) and Candidatus Phytoplasma australiense (8). These designations, as well as others that will be assigned based on analysis of $16 \mathrm{~S}$ rRNA or other conserved genes, imply that the new taxa are (i) phenotypically distinct and (ii) representative of new lineages. Evidence for the latter is required for publication of a provisional phytoplasma taxon $(34,35)$. However, phylogenetically distinct phytoplasmas already have been found to share some phenotypic characters (e.g., production of a virescence-inducing factor), while displaying other characters that are unique (e.g., host range or vector specificity). Thus, the relationship between phytoplasma classification and specific plant diseases and symptoms appears to be only partially congruent.

Current phytoplasma classification schemes provide for recognition of subgroups within major phytoplasma groups $(8,10,15-$ $17,19,26,39,46)$. Subgroup designation carries the presumption that the subgroup population would be judged phenotypically discrete if its phenotype were known. Presumably, subgroups represent distinct gene pools that have become discrete through evolution after isolation from an ancestral population, perhaps by inhabiting different plant or insect hosts or geographic dispersal of ancestral hosts. Although authorities do not yet agree on criteria for differentiating subgroups, recognition of subgroups seems justified, because some of the subgroups delineated based on molecular criteria apparently have other differentiating properties, including restricted host ranges and limited geographic distribution.

On the other hand, recognition of subgroups based only on minor sequence differences (single-base substitutions) in highly conserved genes can be problematic unless correlated with phenotypic differences. Researchers concerned with phytoplasma classification require criteria for interpreting the significance of small differences in conserved sequences among strains within a group. Single-base substitutions in 16S rDNA may represent (i) intraspecific variability not correlated with any other characteristic that could be used to distinguish species or (ii) indicators of other, as yet undetected, genetic and phenotypic differences or geographic distribution of strains. Fox et al. (12) and Stackebrandt (45) pointed out that in other bacteria, sequence homology $>97$ to $98 \%$ in $16 \mathrm{~S} \mathrm{rRNA}$ genes of an array of strains does not necessarily indicate such strains all belong to the same (species level) taxon. We hypothesize that evolutionary divergence of phytoplasma lineages proceeds through selection for ecological fitness determined by other genes. Because phytoplasma-insect vector relationships and insect vector feeding preferences probably play key roles in opening new ecological niches and providing opportunities for divergent evolution, phytoplasma genes determining fitness for multiplication in and transmission by vectors are probable keys in phytoplasma speciation. Thus, phytoplasma strains sharing sequence identity in $16 \mathrm{~S}$ rRNA genes may not belong to the same species, and small differences in a highly conserved phytoplasma gene should be regarded as potential indicators of separate gene pools. Because sequence heterogeneity between the two rRNA operons of a phytoplasma has been indicated $(9,26,28)$, it seems advisable to compare equivalent operons when distinguishing closely related phytoplasma strains.
TABLE 1. Selected strains of phytoplasmas classified based on restriction fragment length polymorphism or putative restriction site analysis of $16 \mathrm{~S}$ rRNA gene sequences

\begin{tabular}{|c|c|c|}
\hline $\begin{array}{l}\text { 16S rRNA group } \\
\text { (subgroup) }^{\mathrm{a}}\end{array}$ & Phytoplasma (strain designation) & $\begin{array}{l}\text { Source } \\
\text { location }\end{array}$ \\
\hline \multicolumn{3}{|c|}{ 16SrI (Aster yellows group) } \\
\hline $\begin{array}{l}\text { I(A) } \\
\text { I(B) } \\
\text { I(C) } \\
\text { I(D) } \\
\text { I(E) } \\
\text { I(F) } \\
\text { I(K) }\end{array}$ & $\begin{array}{l}\text { Tomato big bud (BB) } \\
\text { Michigan aster yellows (MIAY) } \\
\text { Clover phyllody (CPh) } \\
\text { Paulownia witches'-broom (PaWB) } \\
\text { Blueberry stunt (BBS1) } \\
\text { Apricot chlorotic leafroll (ACLR-AY) } \\
\text { Strawberry multiplier (STRAWB 2) }\end{array}$ & $\begin{array}{l}\text { Arkansas } \\
\text { Michigan } \\
\text { Canada } \\
\text { Taiwan } \\
\text { Michigan } \\
\text { Spain } \\
\text { Florida }\end{array}$ \\
\hline \multicolumn{3}{|c|}{ 16SrII (Peanut witches' -broom group) } \\
\hline $\begin{array}{l}\mathrm{II}(\mathrm{A}) \\
\mathrm{II}(\mathrm{B}) \\
\mathrm{II}(\mathrm{C}) \\
\mathrm{II}(\mathrm{D})\end{array}$ & $\begin{array}{l}\text { Peanut witches'-broom (PnWB) } \\
\text { Witches'-broom of lime (WBDL), } \\
\text { "Candidatus } \text { Phytoplasma aurantifolia" } \\
\text { Faba bean phyllody (FBP) } \\
\text { Sweet potato little leaf (SPLL) }\end{array}$ & $\begin{array}{l}\text { Taiwan } \\
\text { Arabian } \\
\quad \text { Peninsula } \\
\text { Sudan } \\
\text { Australia }\end{array}$ \\
\hline \multicolumn{3}{|c|}{ 16SrIII (X-disease group) } \\
\hline $\begin{array}{l}\text { III(A) } \\
\text { III(B) } \\
\text { III(C) } \\
\text { III(D) } \\
\text { III(E) } \\
\text { III(F) } \\
\text { III(G) } \\
\text { III(H) } \\
\text { III(I) }\end{array}$ & $\begin{array}{l}\text { X-disease (CX) } \\
\text { Clover yellow edge (CYE) } \\
\text { Pecan bunch (PB) } \\
\text { Goldenrod yellows (GR1) } \\
\text { Spirea stunt (SP1) } \\
\text { Milkweed yellows (MW1) } \\
\text { Walnut witches'-broom (WWB) } \\
\text { Poinsettia branch-inducing (PoiBI) } \\
\text { Virginia grapevine yellows (VGYIII) }\end{array}$ & $\begin{array}{l}\text { Canada } \\
\text { Canada } \\
\text { Georgia } \\
\text { New York } \\
\text { New York } \\
\text { New York } \\
\text { Georgia } \\
\text { United States } \\
\text { Virginia }\end{array}$ \\
\hline
\end{tabular}

16SrIV (Coconut lethal yellows group)

$\begin{array}{ll}\text { IV(A) } & \text { Coconut lethal yellowing (LY) } \\ \text { IV(B) } & \text { Tanzanian coconut lethal decline (LDT) }\end{array}$

Florida

Tanzania

$16 \mathrm{rV}$ (Elm yellows group)

$\begin{array}{lll}\text { V(A) } & \text { Elm yellows (EY1) } & \text { United Stat } \\ \text { V(B) } & \text { Cherry lethal yellows (CLY) } & \text { China } \\ \text { V(C) } & \text { Flavescence dorée (FD) } & \text { France } \\ & \\ \text { 6SrVI (Clover proliferation group) } & \\ \text { VI(A) } & \text { Clover proliferation (CP) } & \text { Canada } \\ \text { VI(B) } & \text { "Multicipita" phytoplasma } & \text { Canada }\end{array}$

16SrVII (Ash yellows group)

VII(A) Ash yellows (AshY)

New York

16SrVIII (Loofah witches' -broom group)

VIII(A) Loofah witches'-broom (LfWB)

Taiwan

16SrIX (Pigeon pea witches'-broom group)

IX(A) Pigeon pea witches' -broom (PPWB)

Florida

16SrX (Apple proliferation group)

$\begin{array}{ll}\mathrm{X}(\mathrm{A}) & \text { Apple proliferation (AP) } \\ \mathrm{X}(\mathrm{B}) & \text { Apricot chlorotic leafroll (ACLR) } \\ \mathrm{X}(\mathrm{C}) & \text { Pear decline (PD) } \\ \mathrm{X}(\mathrm{D}) & \text { Spartium witches'-broom (SPAR) } \\ \mathrm{X}(\mathrm{E}) & \text { Black alder witches' -broom (BAWB) }\end{array}$

Germany

Italy

Italy

Italy

Germany

16SrXI (Rice yellow dwarf group)

$\begin{array}{lll}\text { XI(A) } & \text { Rice yellow dwarf (RYD) } & \text { Japan } \\ \text { XI(B) } & \text { Sugarcane white leaf (SCWL) } & \text { Thailand } \\ \text { XI(C) } & \text { Leafhopper-borne (BVK) } & \text { Germany }\end{array}$

16SrXII (Stolbur

group)

XII(A)

Stolbur (STOL) [formerly group 16SrI,

Serbia

XII(B) subgroup $\mathrm{G}]$

Australian grapevine yellows (AUSGY), "Candidatus Phytoplasma australiense" [formerly group $16 \mathrm{SrI}$, subgroup J]

16SrXIII (Mexican periwinkle virescence group) XIII(A)
[formerly group 16SrI, subgroup I]

Mexico

16SrXIV (Bermudagrass white leaf group)

XIV(A) Bermudagrass white leaf (BGWL)

Thailand

${ }^{a}$ Lee et al. (25), except for new subgroups 16srI-K, 16SrIII-I, and 16SrVI-B. Location of the source of the representative phytoplasma strain. 
At the current stage of phytoplasma classification, it seems worthwhile to take into account small differences in conserved sequences, while reserving judgment about their possible taxonomic significance. This concept recognizes that different subgroups are not necessarily of equivalent taxonomic rank and decisions on taxonomic recognition of narrowly distinguished subgroups ought to await incorporation of other genomic and phenotypic data that could indicate distinct lineages. Nevertheless, provisional designations are needed as aids for disease diagnosis and related regulatory decisions. Consideration of single-base substitutions in highly conserved genes (e.g., 16S rRNA genes) as potential indicators of separate taxa may be a useful approach that will avoid overlooking biological differences or losing molecular distinctions that could later prove to be correlated with biodiversity and significant biological properties that impact disease epidemiology.

Nucleotide sequence data are not available to assess the number of 16S rRNA base substitutions between some closely related subgroups distinguished on the basis of restriction fragment length polymorphism (RFLP) patterns in 16S rDNA, but the occurrence of different RFLP patterns within any of the principal groups is consistent with consideration of subgroups as collectively representing a "16S rRNA species complex," sensu Fox et al. (12). Thus, although each major group may be considered as representative of at least a single phytoplasma species, the subgroups within a group also may be considered as potentially distinct species belonging to the same 16S rRNA species complex. The stolbur and Australian grapevine yellows subgroups, for example, represent distinct lineages and, consequently, have been recognized as separate Candidatus Phytoplasma species (8).

\section{PHYTOPLASMA IDENTIFICATION AND DISEASE DELINEATION}

The current status of phytoplasma classification and taxonomy raises a practical question: what is the appropriate level of phytoplasma classification at which to differentiate plant pathogens, or what unit of phytoplasma classification should one use to ascribe disease causality? Species is the taxonomic level at which disease causality generally is ascribed in plant pathology. For example, Pantoea stewartii causes Stewart's wilt of sweet corn, and Ralstonia solanacearum causes bacterial wilt of many plants. On the other hand, advances in fungal genetics have produced several examples of multiple fungal species that cause single diseases (e.g., Dutch elm disease and Verticillium wilt [4,5]). A perfect connection between phytoplasma and disease could be envisioned if each phytoplasma taxon were associated with a discrete disease, i.e., an identifiable set of damaging processes that affects a particular set of plant taxa and presents a particular set of symptoms. However, it appears that the connection is imperfect.

Some discrete diseases can be readily ascribed to phytoplasma taxa at the Candidatus species level when equivalent to the $16 \mathrm{~S}$ rRNA group, whereas others are clearly associated with phytoplasma taxa below this level. For example, ash yellows, lethal yellowing of palms, and rice yellow dwarf, respectively, are associated with three of the major groups (prospective Candidatus species) of phytoplasmas. These diseases are discrete in syndrome, spectrum of affected plants, and geographic distribution. However, most phytoplasmal diseases that are sufficiently well characterized for consideration appear to be attributable to strain clusters below the $16 \mathrm{~S}$ rRNA group level, i.e., phytoplasmas belonging to different subgroups often cause different diseases. For example, limited data from the Prunus X group (16S rRNA group III) indicate that different subgroups are responsible respectively for peach X-disease, spirea stunt, milkweed yellows, and pecan bunch $(13,17)$. The occurrence of closely related but distinct phytoplasmas in the same geographic region (eastern United States) is consistent with the hypothesis that they have different insect vectors whose respective plant host feeding preferences maintain mu- tually isolated subgroups. Similarly, in the elm yellows group (16S rRNA group V), it appears that pathogens associated with alder yellows, elm yellows, grapevine flavescence dorée, hemp dogbane yellows, jujube witches'-broom, and perhaps other diseases are distinct based on molecular criteria (14,27,31-33).

There is further evidence that phytoplasmas belonging to different subgroups within a 16S rRNA group can cause different plant diseases. For example, group 16SrXII phytoplasmas in the stolbur subgroup (subgroup A) are acknowledged as the cause of Bois Noir disease of grapevines in Europe and the Mediterranean Region, whereas group $16 \mathrm{SrXII}$ phytoplasmas in subgroup B are associated with Australian grapevine yellows disease. The known geographic ranges of these diseases differ from each other, and it seems reasonable to hypothesize that divergent evolution of the pathogens has given rise to distinct phytoplasma species. Comparative analyses of 16S rRNA gene sequences support this hypothesis and the eventual recognition of subgroups 16SrXII-A and 16 SrXII-B as separate Candidatus Phytoplasma species (8). Although the syndromes caused by these phytoplasmas in grapevines are very similar, the diseases are regarded as different.

\section{SYMPTOMATOLOGY AND PHYTOPLASMAL DISEASE DIAGNOSIS}

When a diseased plant is found, one tends to view the syndrome as indicative of a particular disease. Some syndromes induced by specific phytoplasmas may be sufficiently well characterized to permit reliance on symptoms or microscopy for practical diagnosis (e.g., in places where the disease is already known to occur). Examples include ash yellows, elm yellows, and X-disease of chokecherry, in which available evidence indicates only closely related phytoplasma strains are involved.

Disease diagnosis based on symptoms or microscopy in inappropriate circumstances may lead to an erroneous diagnosis and, subsequently, to misdirected efforts at disease management. Precise diagnosis, including pathogen identification, frequently is necessary for effective disease control. Phytoplasmas causing similar syndromes may be spread by different vectors, and effective control may require intervention in the vector cycle. Accurate diagnosis of many phytoplasmal syndromes requires specific identification of the pathogen, including syndromes known collectively as grapevine yellows, which are caused by at least three phytoplasmas $(1,6,7,30,37,38)$, bigbud of tomato $(11,23,26,42)$, assorted diseases of periwinkle $(18,20,22,26)$, and all phytoplasmal diseases encountered under new circumstances. Specific identification also is needed in cases of different syndromes caused by closely related phytoplasmas. For example, different strains classified in the aster yellows phytoplasma group (16S rRNA group I) may cause identical or different symptoms in the same host species, depending on the strains chosen for comparison $(22,26)$. Understanding the relationship between biological properties and classification based on conserved sequences requires extensive studies of the phytoplasma genome.

\section{CONCLUSIONS}

The use of molecular approaches to detect, identify, and classify phytoplasmas has made it possible to (i) determine consistent associations of some phytoplasmas with specific diseases, (ii) recognize some diseases as complexes of several similar disorders caused by different phytoplasmas, and (iii) unveil infections of individual plants by mixed phytoplasma species. Host species and symptoms can indicate the identity of the causal phytoplasma, but the reliability of a diagnosis based solely on symptoms apparently must be learned empirically (i.e., through case study) for each syndrome. Many plant diseases, but very few symptom syndromes, can be differentiated based solely on current phytoplasma classification schemes. Distantly related phytoplasmas often induce very similar 
symptoms in a host plant, such as periwinkle. Perhaps this situation prevails because phytoplasmas as a group possess relatively few mechanisms for plant pathogenicity or because phytoplasma attributes that permit parasitism of plants are not highly hostspecific. The former would be consistent with the hypothesis of a common ancestral origin of phytoplasma pathogenicity genes and a limited repertoire of plant responses to phytoplasma pathogen signals. The latter would be consistent with the hypothesis that botanical host ranges of some phytoplasmas reflect specificities in transmission by vectors or vector feeding preferences. Additional research is needed to identify linkages between phytoplasma classification and mechanisms of pathogenicity and plant response and to understand the influence of infection by mixed phytoplasma species on the development of disease syndromes.

\section{LITERATURE CITED}

1. Albanese, G., Davis, R. E., Granata, G., Dally, E. L., Santucci, T., and Tessitori, M. 1996. DNA-based analyses to detect and identify phytoplasma yellows-diseased grapevines in Sicily. Petria 6:65-76.

2. Alma, A., Davis, R. E., Vibio, M., Danielli, A., Bosco, D., Arzone, A., and Bertaccini, A. 1996. Mixed infection of grapevines in northern Italy by phytoplasmas including 16S rRNA RFLP subgroup 16SrI-B strains previously unreported in this host. Plant Dis. 80:418-421.

3. Bianco, P. A., Davis, R. E., Prince, J. P., Lee, I.-M., and Belli, G. U. 1993. Double and single infections by aster yellows and elm yellows MLOs in grapevines with symptoms characteristic of flavescence dorée. Riv. Patol. Veg. 3:69-82.

4. Brasier, C. M., and Mehrotra, M. D. 1995. Ophiostoma himal-ulmi sp. nov., a new species of Dutch elm disease fungus endemic to the Himalayas. Mycol. Res. 99:205-215.

5. Carder, J. H. 1989. Distinctions between cellulase isoenzyme patterns of five plant-pathogenic Verticillium species. Mycol. Res. 92:297-301.

6. Daire, X., Clair, D., Larrue, J., and Boudon-Padieu, E. 1997. Survey for grapevine yellows phytoplasmas in diverse European countries and Israel. Vitis 36:53-54.

7. Davis, R. E., Dally, E. L., Bertaccini, A., Credi, R., Osler, R., Savino, V., Carraro, L., di Terlizzi, B., Lee, I.-M., and Barba, M. 1993. Restriction fragment length polymorphism analysis and dot hybridizations distinguish mycoplasmalike organisms associated with flavescence dorée and southern European grapevine yellows disease in Italy. Phytopathology 83: 772-776.

8. Davis, R. E., Dally, E. L., Gundersen, D. E., Lee, I.-M., and Habili, N. 1997. "Candidatus Phytoplasma australiense," a new phytoplasma taxon associated with Australian grapevine yellows. Int. J. Syst. Bacteriol. 47:262269.

9. Davis, R. E., Jomantiene, R., and Dally, E. L. 1998. Interoperon sequence heterogeneity and differential PCR-mediated amplification of sequences from the two rRNA operons in phytoplasma. Page 176 in: Abstr. 12th Int. Org. Mycoplasmology Conf., Sydney, Australia.

10. Davis, R. E., Jomantiene, R., Dally, E. L., Maas, J., Legard, D., and Postman, J. 1998. Possible link between the rare plant taxon "Fragaria multicipita" in Canada and a disease problem in strawberry in Florida. Acta Hortic. 471:25-30.

11. Davis, R. E., Lee, I.-M., Douglas, S. M., Dally, E. L., and Dewitt, N. 1990. Development and use of cloned nucleic acid hybridization probes for disease diagnosis and detection of sequence homologies among uncultured mycoplasmalike organisms (MLOs). Zentralbl. Bakteriol. Suppl. 20:303.

12. Fox, G. E., Wisotzkey, J. D., and Jurtshuk, P., Jr. 1992. How close is close: 16S rRNA sequence identity may not be sufficient to guarantee species identity. Int. J. Syst. Bacteriol. 42:166-170.

13. Griffiths, H. M., Gundersen, D. E., Sinclair, W. A., Lee, I.-M., and Davis, R. E. 1994. Mycoplasmalike organisms from milkweed, goldenrod, and spirea represent two new 16S rRNA subgroups and three new strain subclusters related to peach X-disease MLOs. Can. J. Plant Pathol. 16:255260.

14. Griffiths, H. M., Sinclair, W. A., Lee, I.-M., Boudon-Padieu, E., Daire, X., and Smart, C. 1998. Implications of differences between elm-inhabiting phytoplasmas and others in 16S rRNA group V. (Abstr.). Eur. J. For. Pathol. 28:79.

15. Gundersen, D. E., and Lee, I.-M. 1995. Ultrasensitive detection of phytoplasmas by nested-PCR assays using two universal primer pairs. Phytopathol. Mediterr. 35:144-151.

16. Gundersen, D. E., Lee, I.-M., Rehner, S. A., Davis, R. E., and Kingsbury, D. T. 1994. Phylogeny of mycoplasmalike organisms (phytoplasmas): A basis for their classification. J. Bacteriol. 176:5244-5254

17. Gundersen, D. E., Lee, I.-M., Schaff, D. A., Harrison, N. A., Chang, C. J.,
Davis, R. E., and Kingsbury, D. T. 1996. Genomic diversity and differentiation among phytoplasma strains in 16S rRNA groups I (aster yellows and related phytoplasmas) and III (X-disease and related phytoplasmas). Int. J. Syst. Bacteriol. 46:64-75.

18. Harrison, N. A., Tsai, J. H., and Richardson, P. A. 1996. Etiological and epidemiological investigations of periwinkle witches'-broom disease in Florida. IOM Lett. 4:197-198.

19. Jomantiene, R., Davis, R. E., Maas, J., and Dally, E. L. 1998. Classification of new phytoplasmas associated with diseases of strawberry in Florida based on analysis of 16S rRNA and ribosomal protein gene operon sequences. Int. J. Syst. Bacteriol. 48:269-277.

20. Khew, K. L., Davis, R. E., Ong, C. A., Lee, I. M., Su, H. J., and Tsai, M. C. 1991. Detection of a Malaysian mycoplasmalike organism (MLO) and its differentiation from other Asian, European, and North American MLOs by use of cloned chromosomal and extrachromosomal MLO DNA probes. J. Plant Prot. Trop. 8:167-180.

21. Kirkpatrick, B. C., Smart, C., Gardner, S., Gao, J.-L., Ahrens, U., Mäurer, R., Schneider, B., Lorenz, K.-H., Seemüller, E., Harrison, N., Namba, S., and Daire, X. 1994. Phylogenetic relationships of plant pathogenic MLOs established by 16/23S rDNA spacer sequences. IOM Lett. 3:228-229.

22. Lee, I.-M., Davis, R. E., Chen, T.-A., Chiykowski, L. N., Fletcher, J., Hiruki, C., and Schaff, D. A. 1992. A genotype-based system for identification and classification of mycoplasmalike organisms (MLOs) in the aster yellows MLO strain cluster. Phytopathology 82:977-986.

23. Lee, I.-M., Davis, R. E., and DeWitt, N. D. 1990. Nonradioactive screening method for isolation of disease-specific probes to diagnose plant diseases caused by mycoplasmalike organisms. Appl. Environ. Microbiol. $56: 1471-1475$

24. Lee, I.-M., Gundersen, D. E., Hammond, R. W., and Davis, R. E. 1994. Use of mycoplasmalike organism (MLO) group-specific oligonucleotide primers for nested-PCR assays to detect mixed-MLO infections in a single host plant. Phytopathology 84:559-566.

25. Lee, I.-M., Gundersen-Rindal, D. E., and Bertaccini, A. 1998. Phytoplasma: Ecology and genomic diversity. Phytopathology 88:1359-1366.

26. Lee, I.-M., Hammond, R. W., Davis, R. E., and Gundersen, D. E. 1993. Universal amplification and analysis of pathogen 16S rDNA for classification and identification of mycoplasmalike organisms. Phytopathology 83:834-842.

27. Lee, I.-M., Zhu, S., Gundersen, D. E., Zhang, C., and Hadidi, A. 1995. Detection and identification of a new phytoplasma associated with cherry lethal yellows in China. (Abstr.) Phytopathology 85:1179.

28. Liefting, L. W., Andersen, M. T., Beever, R. E., Gardner, R. C., and Forster, R. L. S. 1996. Sequence heterogeneity in the two 16S rRNA genes of Phormium yellow leaf phytoplasma. Appl. Environ. Microbiol. 62:3133-3139.

29. Lim, P.-O., and Sears, B. B. 1992. Evolutionary relationships of a plant pathogenic mycoplasmalike organism and Acholeplasma laidlawii deduced from two ribosomal protein gene sequences. J. Bacteriol. 174:2606-2611.

30. Maixner, M., Ahrens, U., and Seemüller, E. 1995. Detection of the German grapevine yellows (Vergilbungskrankheit) MLO in grapevine, alternative hosts, and a vector by a specific PCR procedure. Eur. J. Plant Pathol. 101:241-250.

31. Marcone, C., Ragozzino, A., and Seemüller, E. 1997. Identification and characterization of the phytoplasma associated with elm yellows in southern Italy and its relatedness to other phytoplasmas of the elm yellows group. Eur. J. For. Pathol. 27:45-54.

32. Mäurer, R., and Seemüller, E. 1994. Nature and genetic relatedness of the mycoplasma-like organism causing rubus stunt in Europe. Plant Pathol. 44:244-249.

33. Mäurer, R., Seemüller, E., and Sinclair, W. A. 1993. Genetic relatedness of mycoplasmalike organisms affecting elm, alder, and ash in Europe and North America. Phytopathology 83:971-976.

34. Murray, R. G. E., and Schleifer, K. H. 1994. Taxonomic notes: A proposal for recording the properties of putative taxa of procaryotes. Int. J. Syst. Bacteriol. 44:174-176.

35. Murray, R. G. E., and Stackebrandt, E. 1995. Taxonomic note: Implementation of the provisional status Candidatus for incompletely described procaryotes. Int. J. Syst. Bacteriol. 45:186-187.

36. Namba, S., Oyaizu, H., Kato, S., Iwanami, S., and Tsuchizaki, T. 1993. Phylogenetic diversity of phytopathogenic mycoplasmalike organisms. Int. J. Syst. Bacteriol. 43:461-467.

37. Padovan, A. C., Gibb, K. S., Bertaccini, A., Vibio, M., Bonfiglioli, R. E., Magarey, P. A., and Sears, B. B. 1995. Molecular detection of the Australian grapevine yellows phytoplasma and comparison with grapevine yellows phytoplasmas from Italy. Aust. J. Grape \& Wine Res. 1:25-31.

38. Prince, J. P., Davis, R. E., Wolf, T. K., Lee, I.-M., Mogen, B. D., Dally, E. L., Bertaccini, A., Credi, R., and Barba, M. 1993. Molecular detection of diverse mycoplasmalike organisms (MLOs) associated with grapevine yellows and their classification with aster yellows, X-disease, and elm yellows MLOs. Phytopathology 83:1130-1137. 
39. Schneider, B., Gibb, K. S., and Seemüller, E. 1997. Sequence and RFLP analysis of the elongation factor Tu gene used in differentiation and classification of phytoplasmas. Microbiology 143:3381-3389.

40. Schneider, B., and Seemüller, E. 1994. Studies on taxonomic relationships of mycoplasmalike organisms by Southern blot analysis. J. Phytopathol. 141:173-185.

41. Seemüller, E., Schneider, B., Mäurer, R., Ahrens, U., Daire, X., Kison, H., Lorenz, K.-H., Firrao, G., Avinent, L., Sears, B. B., and Stackebrandt, E. 1994. Phylogenetic classification of phytopathogenic mollicutes by sequence analysis of 16 S ribosomal DNA. Int. J. Syst. Bacteriol. 44:440446.

42. Shaw, M. E., Kirkpatrick, B. C., and Golino, D. A. 1993. The beet leafhoppertransmitted virescence agent causes tomato bigbud disease in California. Plant Dis. 77:290-295.

43. Sinclair, W. A., Griffiths, H. M., and Davis, R. E. 1996. Ash yellows and lilac witches'-broom: Phytoplasmal diseases of concern in forestry and horticulture. Plant Dis. 80:468-475.

44. Smart, C. D., Schneider, B., Blomquist, C. L., Guerra, L. J., Harrison, N. A., Ahrens, U., Lorenz, K.-H., Seemüller, E., and Kirkpatrick, B. C. 1996. Phytoplasma-specific PCR primers based on sequences of the 16S-23S rRNA spacer region. Appl. Environ. Microbiol. 62:2988-2993.

45. Stackebrandt, E. 1997. Identifying culturable and uncultured prokaryotes. Symbiosis 22:47-58.

46. Vibio, M., Bertaccini, A., Lee, I.-M., Davis, R. E., and Clark, M. F. 1996. Differentiation and classification of aster yellows and related European phytoplasmas. Phytopathol. Mediterr. 35:33-42.

47. Zreik, L., Carle, P., Bové, J. M., and Garnier, M. 1995. Characterization of the mycoplasmalike organism associated with witches'-broom disease of lime and proposition of a Candidatus taxon for the organism, "Candidatus Phytoplasma aurantifolia.” Int. J. Syst. Bacteriol. 45:449-453. 